\title{
イオン会合性試薬による低分子量アミン類の吸光光度定量 のためのベンジルアミン類の検討
}

\author{
三井 利幸®*，南 幸 男**，藤村 義和*** \\ (1983 年 10 月 25 日受理)
}

\begin{abstract}
低分子量の第 1 ，第 2 アミン類は種々のイオン会合性試薬を用いてもイオン会合体として有機溶媒に 抽出することは困難である. そこで低分子量の第 1 , 第 2 アミン類を塩化ベンジル系試薬と反応させべ ソジル系誘導体とし，イオン会合性試薬を用いて吸光光度法で定量する方法を 13 種類の塩化ベンジル 系試薬についてへキシルアミンを用いて検討した。 その結果，検討した塩化ベンジル系試薬のうち， $\alpha$-クロロ-p-キシレン，p-エチルベンジルクロリド，3,4-ジメチルベンジルクロリド，2,5-ジメチルベ ソジルクロリドが最も検出感度のよい誘導体を形成することが明らかとなった．更に第 1 ，第 2 アミン 類と同様に塩化ベンジル系試薬と反応し誘導体を形成するチオールについても，農薬であるカルタップ を用いて同様に検討したととろ，3,4-ジメチルベンジルクロリド，2,4-ジクロロベンジルクロリド，oニトロベンジルクロリド， $m$-クロロベンジルクロリド，p-エチルベンジルクロリド，p-イオプロピル ベンジルクロリド，3,4-ジクロロベソジルクロリドが最も検出感度のよい誘導体を形成することが明ら かとなった。
\end{abstract}

\section{1 緒言}

低分子量の第 1 , 第 2 アミン類はイオン会合体として 有機溶媒に抽出されにくくイオン会合性試薬を用いた吸 光光度法による定量は不可能である.そこで既にイオン 会合性試薬を用いても定量できないアミン類であるチア ミンを 2,4-ジニトロベンゼン誘導体1)に, 農薬であるカ

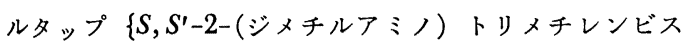
(チオカルバマート)\} やアルカロイド系麻薬であるモル ヒネをべンジル誘導体2)3) とした後, イオン会合性試薬で 吸光光度定量する方法について報告してきた．既にアミ ンの誘導体としては，2,4-ジニトロベンゼン誘導体, べ ンジル誘導体の外に, アシル誘導体, シリル誘導体, ペ ルメチル 誘導体, シッフ 塩基誘導体などの 報告4) があ る. 今回は生成した誘導体がイオン会合体を形成し, 有 機溶媒に抽出されやすい高分子量脂肪族アミンの構造に なるように塩化ベンジル系試薬を用いてベンジル系誘導 体を形成させ, 形成したベンジル系誘導体の中で最も検

* 愛知県科学捜查研究所 : 460 愛知県名古屋市中区 三の丸 2-1-1

** 大阪府整察本部科学捜查研究所：540 大阪府大阪 市東区大手前之町 9

*** 中部工業大学工業化学科：487 愛知県春日井市松 本町 1200
出感度の高い(見掛けのモル吸光係数の大きい)塩化ベン ジル系試薬の検索をへキシルアミンを用いて検討した.

\section{2 試薬及び装置}

\section{1 試 薬}

ヘキシルナミン：市販特級試薬を再蒸留して 使用し た.

塩化ヘンジル系試薬：市販特級試薬をそのまま使用し た.

その他の試薬については低分子量の第 1 , 第 2 , 第 3 フミン類は再蒸留をして, それ以外は市販特級試薬をそ のまま使用した.

カルタップ塩酸塩 : 武田薬品工業(株)製の原体をその まま使用した。

\section{2 装}

分光光度計：日立 624 型デジタル分光光度計. セルは $1 \mathrm{~cm}$ のガラスセルを使用した.

$\mathrm{pH}$ メーター：日立-堀場 $\mathrm{F}-7$ 型 $\mathrm{pH}$ メーターを使 用した。

振り混ぜ機：イワキ V-D 振とう機を使用した.

遠心分離機：クボタ Ks-4000 型遠心分離機を使用し た.

\section{3 操 作}

約 $20 \mathrm{ml}$ の三角フラスコにヘキシルアミンを含有する 
$0.1 \mathrm{M}$ 塩酸水溶液 $1 \mathrm{ml}, 3 \%$ 炭酸ナトリウム水溶液 5 $\mathrm{ml}$, 塩化ベンジル系試薬 $30.0 \mathrm{mg}$, アセトン約 $10 \mathrm{ml}$ 入れ水浴上 $80 \pm 3{ }^{\circ} \mathrm{C}$ で全量が常に一定になるようにア セトンを添加しながら 15 分間加熱する. 次にアセトン を添加しないで 15 分間同一条件で加熱しアセトンを完 全に蒸発除去する. 三角フラスュを氷一水浴に入れ 冷却 後, クロロホルム $10 \mathrm{ml}$ を加え 30 秒間振り混ぜる.こ れを $15 \mathrm{ml}$ の試験管に移し $3000 \mathrm{rpm}$ で 2 分間遠心分離 する. 次いで $15 \mathrm{ml}$ の試験管にクロロホルム相の $5 \mathrm{ml}$ を移し採り, pH 2.09 の Britton-Robinson の広域緩衝 液 $2 \mathrm{ml}$, トロペオリン OO の飽和溶液 $1 \mathrm{ml}$ を加え 2 分間振り混ぜた後 $3000 \mathrm{rpm}$ で 2 分間遠心分離する. 得 られた下層のクロロホルム $2 \mathrm{ml}$ を採り $10 \%$ 塩酸のメ タノール溶液 $0.5 \mathrm{ml}$ を加え $543 \mathrm{~nm}$ で吸光度を測定し た。

\section{4 実験結果及び考察}

\section{1 操作条件の検討}

3 の操作条件を決定するために，添加する炭酸ナトリ ウム及び塩化ベンジル系試薬（条件決定には塩化ベンジ ルを使用した）量，反応温度，反応時間，添加トロペオ リン $\mathrm{OO}$ 量, 抽出溶媒, 最適 $\mathrm{pH}$ 域, 遠心分離の時 間について，各々の最適条件をへキシルアミン $2.45 \times$ $10^{-4} \mathrm{M}$ を用い検討した. 最適条件を Table 1 亿示す. 本実験では，これらの条件をすべて満足する 3 の操作方 法で行らこととした。

Table 1 Operating conditions for measurement

\begin{tabular}{lc}
\hline Concentration of $\mathrm{Na}_{2} \mathrm{CO}_{3}$ & $1.5 \sim 15 \%$ \\
Benzyl chloride added & $>10$ molar ratio \\
Tropaeoline OO added & $>2.5$ molar ratio \\
pH & 2.09 \\
Shaking time & $>1 \mathrm{~min}$ \\
Centrifuging time (3000 rpm) & $>1 \mathrm{~min}$ \\
Optimum solvent for extraction & $\mathrm{CH}_{2} \mathrm{Cl}_{2}, \mathrm{CHCl}_{3}$ \\
\hline
\end{tabular}

Hexylamine : $2.45 \times 10^{-4} \mathrm{M}$

又ヘキシルアミン(ヘキシルアミンのベンジル誘導体) とトロペオリン OO とのイオン会合体の組成比を連続 変化法で求めたところ, ヘキシルアミン：トロペオリン $\mathrm{OO}=1: 1$ であることが明らかとなった. 更に生成した ベンジル 誘導体の 構造式を 赤外吸収法(IR)，核磁気共 鳴法 (NMR)，ガスクロマトグ ラフ 質量分析法 (GG/ MS) で確認した. その結果 IR から第 3 アミンの吸収 帯である $1080 \mathrm{~cm}^{-1}, 1040 \mathrm{~cm}^{-1}$, ベンゼン環の吸収帯 である $3030 \mathrm{~cm}^{-1}$ 近辺, $1500 \mathrm{~cm}^{-1}, 1460 \mathrm{~cm}^{-1}, 750$ $\mathrm{cm}^{-1}, 700 \mathrm{~cm}^{-1}, \mathrm{C}-\mathrm{H}$ 結合による吸收帯である 3000〜
$2800 \mathrm{~cm}^{-1}$ に吸収が認められた。 ${ }^{13} \mathrm{C}$ の NMR から ベンゼン環の化学シフト ( $\delta / \mathrm{ppm})$ 127.02, 127.67, $128.52,128.97$ とアミンの化学シフト $(\delta / \mathrm{ppm}) 31.71$, 37.10 が認められた. GC/MS から親ピークである $m /$ z 282, フラグメントピークである $m / z 91,190,210$ が 認められた。これらの結果から

$$
\mathrm{CH}_{3}\left(\mathrm{CH}_{2}\right)_{5} \mathrm{~N}<\begin{aligned}
& \mathrm{CH}_{2} \mathrm{C}_{6} \mathrm{H}_{5} \\
& \mathrm{CH}_{2} \mathrm{C}_{6} \mathrm{H}_{5}
\end{aligned}
$$

であることが明らかとなった.なお第 2 アミン類はベン ジルの 1 置換体を生成するが, 第 3 アミン類は塩化ベン ジル系試薬とは反応しないためベンジル誘導体形成によ る感度上昇を図ることは不可能であった。

\section{2 分配係数の測定}

13 種類の塩化ベンジル系試薬を用いて，3 の操作にお いてトロペオリンOO, Britton-Robinson の広域緩衝 液を添加振り混ぜた後, ヘキシルアミンのベンジル系誘 導体をイオン会合体としてクロロホルムに抽出した後の クロロホルム相中のベンジル系誘導体量と水相中に移動 したベンジル誘導体量との割合を高速液体クロマトグラ フィー (HPLC) を用いて求めた. 結果を Table 2 に 示した. ここで 3,4-ジメチルベンジルクロリドは 4.00 の值を示しているが，これは市販試薬中に約 $34 \%$ の 2,3-ジメチルベンジルクロリドが混入しているためで, 2,3-ジメチルベンジルクロリドからの誘導体を加え補正 すると分配係数は 5.94 となり高い値を示した。

HPLC の最適測定条件を Table 3 に示した.

Table 2 Apparent molar absorptivity and partition constant for hexylamine derivatives

\begin{tabular}{lcc}
\hline \multicolumn{1}{c}{ Reagents } & $\begin{array}{c}\text { Apparent molar } \\
\text { absorptivity }\end{array}$ & $\begin{array}{c}\text { Partition constant } \\
\left(\mathrm{CHCl}_{3} / \mathrm{H}_{2} \mathrm{O}\right)\end{array}$ \\
\hline$p-\mathrm{CH}_{3} \mathrm{C}_{6} \mathrm{H}_{4} \mathrm{CH}_{2} \mathrm{Cl}$ & 42000 & 5.71 \\
$2,5-\left(\mathrm{CH}_{3}\right)_{2} \mathrm{C}_{6} \mathrm{H}_{3} \mathrm{CH}_{2} \mathrm{Cl}$ & 41000 & 5.51 \\
$3,4-\left(\mathrm{CH}_{3}\right)_{2} \mathrm{C}_{6} \mathrm{H}_{3} \mathrm{CH}_{2} \mathrm{Cl}$ & 39000 & $5.94 \dagger(4.00) \dagger \dagger$ \\
$p-\mathrm{C}_{2} \mathrm{H}_{5} \mathrm{C}_{6} \mathrm{H}_{4} \mathrm{CH}_{2} \mathrm{Cl}$ & 33000 & 4.57 \\
$o-\mathrm{ClC}_{6} \mathrm{H}_{4} \mathrm{CH}_{2} \mathrm{Cl}$ & 30000 & 4.04 \\
$\mathrm{C}_{6} \mathrm{H}_{5} \mathrm{CH}_{2} \mathrm{Cl}_{p}$ & 28000 & 4.38 \\
$p-\left(\mathrm{CH}_{3}\right)_{2} \mathrm{CHC}_{6} \mathrm{H}_{4} \mathrm{CH}_{2} \mathrm{Cl}$ & 28000 & 4.60 \\
$2,4-\mathrm{Cl}_{2} \mathrm{C}_{6} \mathrm{H}_{3} \mathrm{CH}_{2} \mathrm{Cl}$ & 26000 & 4.24 \\
$p-\mathrm{ClC}_{6} \mathrm{H}_{4} \mathrm{CH}_{2} \mathrm{Cl}$ & 24000 & 3.65 \\
$m-\mathrm{ClC}_{6} \mathrm{H}_{4} \mathrm{CH}_{2} \mathrm{Cl}$ & 22000 & 4.19 \\
$3,4-\mathrm{Cl}_{2} \mathrm{C}_{6} \mathrm{H}_{3} \mathrm{CH}_{2} \mathrm{Cl}$ & 19000 & 4.49 \\
$p-\mathrm{NO}_{2} \mathrm{C}_{6} \mathrm{H}_{4} \mathrm{CH}_{2} \mathrm{Cl}$ & 18000 & 3.70 \\
$o-\mathrm{NO}_{2} \mathrm{C}_{6} \mathrm{H}_{4} \mathrm{CH}_{2} \mathrm{Cl}$ & 17000 & 4.13 \\
\hline
\end{tabular}

Hexylamine $\left(2.45 \times 10^{-4} \mathrm{M}\right)$ was used for the determination of partition constant. Commercial 3,4-dimethylbenzyl chloride containing about 34 per cent 2,3-dimethylbenzyl chloride. $\dagger 3,4-\left(\mathrm{CH}_{3}\right)_{2} \mathrm{C}_{6} \mathrm{H}_{3} \mathrm{CH}_{2} \mathrm{Cl}+2,3-\left(\mathrm{CH}_{3}\right)_{2} \mathrm{C}_{6} \mathrm{H}_{3} \mathrm{CH}_{2} \mathrm{Cl}$; if $3,4-$ $\left(\mathrm{CH}_{3}\right)_{2} \mathrm{C}_{6} \mathrm{H}_{3} \mathrm{CH}_{2} \mathrm{Cl}$ 
Table 3 Operating conditions for high performance liquid chromatography

\begin{tabular}{ll}
\hline Column & Zorbax \\
& $4 \mathrm{~mm} \mathrm{i.} \mathrm{dP} . \times 250 \mathrm{~mm}$ \\
Mobile phase & Place $760 \mathrm{ml}$ of $\mathrm{CH}_{2} \mathrm{Cl}_{2}, 40 \mathrm{ml}$ of \\
& $\mathrm{CH}_{3} \mathrm{OH}$, and $80 \mathrm{ml}$ of $1.4 \mathrm{M} \mathrm{NH} \mathrm{H}_{4} \mathrm{OH}$ \\
& in a 11 separatory funnel. Shake it \\
& for $2 \mathrm{~min}$ and allow to stand for $3 \mathrm{~h}$. \\
& Organic phase was used as a mobile \\
phase. & $1.0 \mathrm{ml} / \mathrm{min}$ \\
Flow rate of mobile phase & Room temperature $\left(15 \sim 20^{\circ} \mathrm{C}\right)$ \\
Temperature & $264 \mathrm{~nm}$ \\
Detecting wavelength &
\end{tabular}

Hexylamine : $2.45 \times 10^{-4} \mathrm{M}$

\section{3 見掛けのモル吸光俰数の測定}

13 種類の塩化ベンジル系試薬を用いて, 3 の操作によ り各々の見掛けのモル吸光係数を求めた. 結果を Table 2 に示した.

Table 2 に示した分配係数と見掛けのモル吸光係数の 結果から，ヘキシルアミンの誘導体形成に用いる塩化ベ ンジル系試薬としては， $\alpha$-クロロ-p-キシレン, $p$-エチ ルベンジルクロリド，3,4-ジメチルベンジルクロリド, 2,5-ジメチルベンジルクロリドが低分子量第 1 , 第 2 ア ミン類の定量に対し高感度で測定可能となるものと考え られる。

参考としてベンジル系誘導体としないアミン類及び p-メチルベンジル系誘導体とした一部のアミン類の見掛 けのモル吸光係数を Table 4 に示した.

\section{4 カルタップの 分配保数及び 見掛けのモル吸光係} 数

塩化ベンジル系試薬は水酸基3) とも反応しベンジル誘 導体を形成する.これを利用し，このままではイオン会 合体を形成し有機溶媒に抽出されない第 3 アミンであり チオールでもあるカルタップについてヘキシルアミンと 同様な検討を試みた．操作方法については既に報告した 方法2)で行った. 結果を Table 5 に示した. この結果 から明らかなよらにカルタップは 3,4-ジメチルベンジ ルクロリド，2,4-ジクロロベンジルクロリド，o-ニトロ ヘンンシルクロリド， $m$-クロロベンジルクロリド， $p$-エ チルベンジルクロリド，p-イソプロピルベンジルクロリ ド，3,4-ジクロロベンジルクロリドを用いて誘導体形成 を行えば高感度で定量可能となることが明らかとなっ た. なおカルタップはヘキシルアミンと比較して, 塩化 ベンジル系試薬間による分配係数, 見掛けのモル吸光係 数のばらつきがともに小さく, 全体として分配係数, 見 脚けのモル吸光係数いずれもが大きな数值を示してい
Table 4 Apparent molar absorptivity of amines

\begin{tabular}{|c|c|c|c|}
\hline Compounds & $\begin{array}{l}\text { Apparent molar } \\
\text { absorptivity }\end{array}$ & Compounds & $\begin{array}{l}\text { Apparent molar } \\
\text { absorptivity }\end{array}$ \\
\hline Methylamine & $0 \quad(9000)$ & $m$-Toluidine & 600 \\
\hline Ethylamine & $0 \quad(9000)$ & $p$-Toluidine & 1000 \\
\hline Butylamine & $\begin{array}{ll}0 & (9000)\end{array}$ & $o$-Anisidine & 500 \\
\hline Isobutylamine & $0 \quad(9000)$ & $m$-Anisidine & 400 \\
\hline Hexylamine & $1000(42000)$ & $p$-Anisidine & 2000 \\
\hline Octylamine & 45000 & $o$-Aminophenol & 600 \\
\hline Decylamine & 22000 & $m$-Aminophenol & 400 \\
\hline Diethylamine & $4000(20000)$ & $p$-Aminophenol & 400 \\
\hline Dipropylamine & 11000 & $N$-Methylaniline & 2000 \\
\hline Dibutylamine & 27000 & $N$-Ethylaniline & 4000 \\
\hline Dioctylamine & 56000 & $N, N$-Dimethyl- & 5000 \\
\hline Didecylamine & 52000 & & \\
\hline Trimethylamine & 400 & $\begin{array}{l}N, N \text {-Dimethyl- } \\
\text { nitrosoaniline }\end{array}$ & 700 \\
\hline $\begin{array}{l}\text { Triethylamine } \\
\text { Tributylamine }\end{array}$ & $\begin{array}{l}35000 \\
40000\end{array}$ & $\begin{array}{c}p \text {-Amino- } N, N- \\
\text { diethylaniline }\end{array}$ & 37000 \\
\hline Cyclohexylamine & 7000 & 2,4-Toluenediamine & ne 600 \\
\hline $\begin{array}{l}\text { Triethylenete- } \\
\text { tramine }\end{array}$ & 2000 & $o$-Phenylenediamine & ne 1000 \\
\hline $\begin{array}{l}\text { Cetyltrimethyl } \\
\text { ammoniumchloride }\end{array}$ & $\mathrm{de}^{22000}$ & 2-Naphthylamine & 400 \\
\hline 2-Aminopyridine & 12000 & $\begin{array}{l}N \text {-Ethyl-1-naphthyl } \\
\text { amine }\end{array}$ & yl- 1000 \\
\hline $\begin{array}{l}\text { Piperazine } \\
\text { Pyperidine }\end{array}$ & $\begin{array}{l}1000 \\
8000\end{array}$ & $\begin{array}{l}N \text {-Phenyl-1- } \\
\text { naphthylamine }\end{array}$ & 1000 \\
\hline $\begin{array}{l}\text { Aniline } \\
o \text {-Toluidine }\end{array}$ & $\begin{array}{l}300(18000) \\
500\end{array}$ & $\begin{array}{l}N \text {-Phenyl-2- } \\
\text { naphthylamine }\end{array}$ & 700 \\
\hline
\end{tabular}

Ethanolamine, Diethanolamine, Ethylenediamine, Dipicrylamine, $o$-Nitroaniline, $m$-Nitroaniline, $p$-Nitroaniline, Diphenylamine, $p$-Methylaminophenol, 4-Nitro-1-naphthylamine, $o$-Chloroaniline, and $p$-Aminohippuric acid could not be determined. The values in parentheses are those for the respective $N, N$-di-p-methylbenzylamines. The procedure is as follows. Water-soluble sample : Place $1 \mathrm{ml}$ of sample solution, $1 \mathrm{ml}$ of saturated Tropaeoline OO solution, $2 \mathrm{ml}$ of a buffer solution $(\mathrm{pH} 2.09)$, and $5 \mathrm{ml}$ of $\mathrm{CHCl}_{3}$. Shake the solution for $2 \mathrm{~min}$ mechanically, and centrifuge for $2 \mathrm{~min}$ at $3000 \mathrm{rpm}$. Take $2 \mathrm{ml}$ of the $\mathrm{CHCl}_{3}$ phase, and add $0.5 \mathrm{ml}$ methanol solution of $10 \% \mathrm{HCl}$ and measure the absorbance at $543 \mathrm{~nm}$. Water-insoluble sample: Place $1 \mathrm{ml}$ of water, $1 \mathrm{ml}$ of Tropaeoline OO solution, $2 \mathrm{ml}$ of a buffer solution $(\mathrm{pH}$ 2.09), and $5 \mathrm{ml}$ of sample in $\mathrm{CHCl}_{3}$. Shake the solution for $2 \mathrm{~min}$ mechanically, and centrifuge for $2 \mathrm{~min}$ at $3000 \mathrm{rpm}$. Take $2 \mathrm{ml}$ of the $\mathrm{CHCl}_{3}$ phase, and add $0.5 \mathrm{ml}$ of methanol solution of $10 \% \mathrm{HCl}$ and measure the absorbance at $543 \mathrm{~nm}$.

る. 又 3,4-ジメチルベンジルクロリドについてはへキ シルアミンの場合と同様に約 $34 \%$ 共存している 2,3 ジメチルベンジルクロリドからの誘導体の分配係数を加 え補正すると 4.88 となった. 分配係数の測定は HPLC を用いヘキシルアミンと同一条件で行った. 塩化ベン ジルを用いて作製したベンジル誘導体の構造式を IR， NMR，GC/MS で確認した. その結果 IR から第3ア ミンの吸収帯である $1080 \mathrm{~cm}^{-1}, 1030 \mathrm{~cm}^{-1}$, ベンゼン 環の吸収帯である $3030 \mathrm{~cm}^{-1}$ 近辺, $1500 \mathrm{~cm}^{-1}, 1460$ $\mathrm{cm}^{-1}, 700 \mathrm{~cm}^{-1}, \mathrm{C}-\mathrm{H}$ 結合による吸収帯である 3000〜 $2800 \mathrm{~cm}^{-1}$ に吸収が認められた。 ${ }^{13} \mathrm{C}$ の NMR から ベンゼン環の化学シフト $(\delta / \mathrm{ppm}) 127.02,127.67$, $128.52,128.97$, アミンの化学シフト $(\delta / \mathrm{ppm}) 31.71$, 
Table 5 Apparent molar absorptivity and partition constant for agricultural chemical Gartap

\begin{tabular}{lcc}
\hline \multicolumn{1}{c}{ Reagents } & $\begin{array}{c}\text { Apparent molar } \\
\text { absorptivity }\end{array}$ & $\begin{array}{c}\text { Partition constant } \\
\left(\mathrm{CH}_{2} \mathrm{Cl}_{2} / \mathrm{H}_{2} \mathrm{O}\right)\end{array}$ \\
\hline $3,4-\left(\mathrm{CH}_{3}\right)_{2} \mathrm{C}_{6} \mathrm{H}_{3} \mathrm{CH}_{2} \mathrm{Cl}$ & 48000 & $4.88 \dagger(4.70)+\dagger$ \\
$2,4-\mathrm{Cl}_{2} \mathrm{C}_{6} \mathrm{H}_{3} \mathrm{CH}_{2} \mathrm{Cl}$ & 48000 & 6.03 \\
o- $\mathrm{NO}_{2} \mathrm{C}_{6} \mathrm{H}_{4} \mathrm{CH}_{2} \mathrm{Cl}$ & 46000 & 5.10 \\
$m-\mathrm{ClC}_{6} \mathrm{H}_{4} \mathrm{CH}_{2} \mathrm{Cl}$ & 45000 & 5.46 \\
$p-\mathrm{C}_{2} \mathrm{H}_{5} \mathrm{C}_{6} \mathrm{H}_{4} \mathrm{CH}_{2} \mathrm{Cl}$ & 45000 & 5.78 \\
$p-\left(\mathrm{CH}_{3}\right)_{2} \mathrm{CHC}_{6} \mathrm{H}_{4} \mathrm{CH}_{2} \mathrm{Cl}$ & 45000 & 5.78 \\
$3,4-\mathrm{Cl}_{2} \mathrm{C}_{6} \mathrm{H}_{3} \mathrm{CH}_{2} \mathrm{Cl}$ & 45000 & 4.70 \\
$\mathrm{C}_{6} \mathrm{H}_{5} \mathrm{CH}_{2} \mathrm{Cl}_{0}$ & 45000 & 4.58 \\
o- $\mathrm{ClC}_{6} \mathrm{H}_{4} \mathrm{CH}_{2} \mathrm{Cl}$ & 36000 & 6.19 \\
$p-\mathrm{CH}_{3} \mathrm{C}_{6} \mathrm{H}_{4} \mathrm{CH}_{2} \mathrm{Cl}$ & 35000 & 5.22 \\
$2,5-\left(\mathrm{CH}_{3}\right)_{2} \mathrm{C}_{6} \mathrm{H}_{3} \mathrm{CH}{ }_{2} \mathrm{Cl}$ & 35000 & 4.10 \\
$p-\mathrm{ClC}_{6} \mathrm{H}_{4} \mathrm{CH}_{2} \mathrm{Cl}$ & 34000 & 5.42 \\
$p-\mathrm{NO}_{2} \mathrm{C}_{6} \mathrm{H}_{4} \mathrm{CH}_{2} \mathrm{Cl}$ & 31000 & 4.43 \\
\hline
\end{tabular}

Cartap $\left(2.12 \times 10^{-4} \mathrm{M}\right)$ was used for determination of partition constant. Commercial 3,4-dimethylbenzyl chloride containing about 34 per cent of 2,3-dimethylbenzyl chloride. $†$ 3,4$\left(\mathrm{CH}_{3}\right)_{2} \mathrm{C}_{6} \mathrm{H}_{3} \mathrm{CH}_{2} \mathrm{Cl}+2,3-\left(\mathrm{CH}_{3}\right)_{2} \mathrm{C}_{6} \mathrm{H}_{3} \mathrm{CH}_{2} \mathrm{Cl}$; if 3,4- $\left(\mathrm{CH}_{3}\right)_{2}-$ $\mathrm{C}_{6} \mathrm{H}_{3} \mathrm{CH}_{2} \mathrm{Cl}$

37.10 が認められた. GC/MS から親ピークである $\mathrm{m} /$ $z 333$, フラグメントピークである $m / z 194,288$ が認 められた.これらの結果から

$$
\begin{aligned}
& \mathrm{CH}_{3} \\
& \mathrm{CH}_{3}
\end{aligned}>\mathrm{N}-\mathrm{CH}\left\langle\begin{array}{l}
\mathrm{CH}_{2}-\mathrm{S}-\mathrm{CH}_{2} \mathrm{C}_{6} \mathrm{H}_{5} \\
\mathrm{CH}_{2}-\mathrm{S}-\mathrm{CH}_{2} \mathrm{C}_{6} \mathrm{H}_{5}
\end{array}\right.
$$

であることが明らかとなった.

参考としてカルタップの構造式及び加水分離によって 生成するジヒドロネライストキシン（カルタップはベン ジル系誘導体を形成するときはこの形で反応する）の構 造式を次に示す.<smiles>CN(C)CC(CSC(N)=O)CSC(N)=O</smiles>

\section{交献}

1）三井利幸, 藤村義和：分化，32，264（1983).
2) 三井利幸, 藤村義和 : 分化, 32, 416 (1983).

$3)$ 三井利幸, 藤村義和 : 衛生化学, 29, 292 (1983).

4) D. R. Knapp : "Handbook of Analytical Derivatization Reactions", p. 71 (1979), (John Wiley \& Sons, New York).

$$
\text { 负 }
$$

Examination of benzylamines for spectrophotometric determination of low molecular amines by ion association reagent. Toshiyuki Mrtsui*, Yukio Minami**, and Yoshikazu Fujımura*** (*Criminal Science Laboratory, Aichi Prefecture, 2-1-1, Sannomaru, Naka-ku, Nagoya-shi, Aichi, 460; **Scientific Investigation Research Laboratoy, Osaka Prefectural Police, 9, Otemaeno-cho, Higashi-ku, Osaka-shi, Osaka, 540; ***Department of Industrial Chemistry, Chubu Institute of Technology, 1200 Matsumoto-cho, Kasugai-shi, Aichi, 487)

The low molecular weight primary and secondary amines cannot be extracted by ion association reagent (Tropaeoline OO) and cannot be determined by spectrophotometric method. But the low molecular weight primary and secondary amines react with 13 kinds of benzylchlorides to form their derivatives, which are extracted into chloroform or dichloromethane at $\mathrm{pH}$ 2.09 in the presence of Tropaeoline OO forming an ion association complex. The procedure is as follows; Place $1 \mathrm{ml}$ of the sample solution, $30.0 \mathrm{mg}$ of benzylchlorides, $10 \mathrm{ml}$ of acetone, and $5 \mathrm{ml}$ of $3 \%$ sodium carbonate solution in a $20 \mathrm{ml}$ Erlenmyer's flask. Warm it in a water bath for $15 \mathrm{~min}$ on adding acetone, and for $15 \mathrm{~min}$ without adding acetone at $80 \pm 3{ }^{\circ} \mathrm{C}$. After cooling, add $10 \mathrm{ml}$ of chloroform or dichloromethane. Shake it for $30 \mathrm{~s}$ and place it a $15 \mathrm{ml}$ test tube. Centrifuge for $2 \mathrm{~min}$ at $3000 \mathrm{rpm}$. In a $15 \mathrm{ml}$ test tube, place $5 \mathrm{ml}$ of the organic phase, $1 \mathrm{ml}$ of a saturated Tropaeoline OO solution, and $2 \mathrm{ml}$ of a buffer solution ( $\mathrm{pH}$ 2.09). Shake the solution for $2 \mathrm{~min}$ mechanically, and centrifuge for $2 \mathrm{~min}$. Take $2 \mathrm{ml}$ of the organic phase, and add $0.5 \mathrm{ml}$ of methanol solution of $10 \%$ hydrochloric acid and measure the absorbance at $543 \mathrm{~nm}$. $\alpha$-Chloro- $p$-xylene, $p$-ethyl benzylchloride, 3,4-dimethyl benzylchloride, and 2,5dimethyl benzylchloride produce the hexylamine derivatives which are high sensitive for spectrophotometric determination.

(Received October 25, 1983)

\section{Keyword phrases}

low molecular amines; benzylamines; spectrophotometric determination; Tropaeoline OO. 